\title{
Мінімізація втрат бюджетної програми при зменшенні їі фінансування
}

\section{Павло Пархоменко ${ }^{\mathrm{A}}$}

Received: April 1, 2020 | Revised: April 21, 2020 | Accepted: April 30, 2020

JEL Classification: G12, H23, J38.

DOI: $10.33445 /$ sds.2020.10.2.11

\begin{abstract}
Анотація
Розглянута одна із проблем, що виникає у повсякденній практиці керівного складу розпорядників коштів при прийнятті управлінських рішень. А саме - необхідність перерозподілу асигнувань між бюджетними програмами та обраними заходами, скорочення фінансування, яких найменше позначиться на результативності програми та мінімізує ризики невиконання програми в цілому.

Для розв'язання проблеми запропонований підхід із застосуванням статистичного методу кількісного аналізу ризиків на підставі визначення двох показників: імовірності отримання втрат (збитків) у випадку скорочення фінансування програми та середнього значення і діапазону коливання цих очікуваних втрат (збитків).

Наведений приклад використання запропонованого підходу для двох можливих варіантів скорочення фінансування деякої програми між трьома потенційними групами заходів цієї програми. Запропонований механізм зведення розрахунків у підсумкову таблицю, прийнятну для аналізу та прийняття кінцевого рішення в інстанції управління стосовно вибору найменш ризикового варіанту.

Зазначено, що розглянутий підхід може бути застосований і при наявності більш ніж двох альтернативних варіантів скорочення фінансування програми та для більш ніж трьох потенційних груп заходів що обираються для зменшення фінансування.
\end{abstract}

Ключові слова: варіант скорочення фінансування програми, імовірність втрат (збитків), середнє значення втрат (збитків), коефіцієнт варіації втрат (збитків).

\section{Постановка проблеми}

Незважаючи на суттєве зростання фінансування потреб збройних Сил України в останні роки в практиці органів військового управління - розпорядників коштів виникає необхідність скорочення фінансування деяких бюджетних програм та вибору заходів для зменшення або припинення їх фінансування. Існуюча практика перегляду обсягів фінансування бюджетних програм базується на директивах вищих рівнів управління та на емпіричному досвіді посадових осіб, що приймають рішення.
Однак, в деяких випадках може виникнути доцільність об'єктивного порівняльного оцінювання способу (варіанту) скорочення, щоб мінімізувати ризики невиконання програми в цілому.

Тому питання удосконалення роботи 3 підготовки даних для прийняття рішень щодо перегляду фінансування програм забезпечення збройних сил 3 метою раціонального використання бюджетних фінансових ресурсів $\epsilon$ актуальним і має і відомче, і державне значення.

\footnotetext{
А Національний університет оборони України імені Івана Черняховського, Україна, старший викладач кафедри економіки та фінансового забезпечення, e-mail: mpar88@ukr.net
} 


\section{Аналіз останніх досліджень та публікацій}

Питання державної важливості обґрунтованого та раціонального витрачання обмеженого фінансового ресурсу для ЗС України констатовані у вітчизняних нормативно-правових документах, а також розглядаються у науковому i практичному фаховому середовищі на протязі останніх років в роботах вітчизняних вчених Горбуліна В. П., Шеховцова В. С., Шевцова А. І. [2], Ткача І.М.[1; 5; 6], Іванова І. М. [3], Павловського І. В., Чепкова І. Б., Борохвостова В. К., Рябця О. М., Борохвостова І. В. [4].

\section{Постановка завдання}

Незважаючи на багаторічну регламентовану у нормативно-правовій базі практику виконання, корегування та перегляду бюджетних програм і професійний досвід осіб - розпорядників коштів, існує необхідність розвитку і застосування наукових підходів та створення для осіб, що готують рішення, нескладних, негроміздких методик з обґрунтування найбільш доцільних варіантів перегляду програм 3 метою мінімізації втрат їх результативності.

Метою статті $\epsilon$ розробка прийнятного для практичного використання підходу до вибору варіантів скорочення фінансування бюджетної програми за умови мінімізації втрати ії результативності та ризиків її невиконання.

\section{Виклад основного матеріалу}

При прийнятті управлінських рішень розпорядниками бюджетних коштів щодо перерозподілу (перепризначення) асигнувань між бюджетними програмами (підпрограмами) для об'єктів фінансового забезпечення виникає необхідність в оцінюванні ризиків негативних наслідків у випадку зменшення фінансування деякої програми. Тобто постає необхідність оцінювання (прогнозування) наслідків зменшення (або повного припинення) фінансування деяких заходів в рамках конкретної програми.

Це, в свою чергу, потребує обґрунтованого вибору для яких саме заходів та у яких пропорціях між ними в рамках програми, що підлягає скороченню, можна зменшити (або припинити) фінансування. Обґрунтування вибору необхідно для того, щоб мінімізувати втрати результативності виконання програми та ризики не виконання програми в цілому i, тим самим, сприяти збереженню результативності (ефективності) витрачання бюджетних коштів. Під ризиком будемо розуміти імовірність невиконання програми, втрати або суттєвого зменшення ії результативності (ефективності). Під збереженням результативності програми будемо розуміти мінімізацію збитків для ії заходів. Зрозуміло, що самі збитки неможливо уникнути взагалі, якщо зменшується або припиняється фінансування програми. Тобто у випадку неминучого скорочення фінансування програми постає питання - які саме заходи обрати для скорочення фінансування, тобто для нанесення збитків програмі, який варіант переліку заходів доцільно обрати для того, щоб мінімізувати втрати результативності програми в цілому.

Якщо при прийнятті рішення про скорочення деяких заходів програми або програми в цілому очікувані наслідки відомі і можуть бути оцінені у грошовому виміру як збитки, то і кінцеві наслідки скорочення фінансування програми можуть бути прораховані як певна сума очікуваних збитків.

Якщо на момент прийняття рішення про скорочення фінансування програми наслідки від скорочення можуть бути оцінені не як точні, а як можливі (тобто імовірні) збитки, то для кількісного обґрунтування управлінських 
рішень можуть бути застосовані імовірнісні підходи оцінювання ситуацій.

Одними з підходів до розв'язання подібної управлінської задачі може бути застосування статистичного методу кількісного аналізу ризиків.

Даний метод полягає у вивченні статистики подій при прийнятті управлінських рішень і заснований на визначенні двох чинників:

1. Імовірності події.

2. Величини (ступеню) ризику появи події. Імовірність події означає можливість отримання певного результату. У випадку зменшення фінансування деякої програми можливість отримання втрат, збитків.

Величина (або ступінь) ризику вимірюється двома показниками: середнім очікуваним значенням результату та коливанням (змінністю) можливого результату, тобто можливих втрат, збитків при зменшенні фінансування програми .

Середнє (середнє-арифметичне) очікуване значення пов'язане із невизначеністю ситуації, тобто із невизначеністю наслідків (втрат, збитків), при скороченні фінансування програми. Воно визначається у вигляді середньозваженої величини $B(x)$ всіх можливих результатів - (втрат, збитків), де імовірність $P_{n}$ кожного окремого результату (тобто заходу $n$, що підлягає скороченню фінансування) використовується у якості коефіцієнта “ваги" відповідного значення $x_{n}$ окремого результату (тобто втрати, збитку).

У загальному вигляді це можна записати так:

$$
B(x)=P_{1} x_{1}+P_{2} x_{2}+\ldots+P_{n} x_{n}
$$

Розглянемо зазначений підхід на прикладі.

Припустимо, що необхідно прийняти рішення про зменшення обсягів фінансування певної бюджетної підпрограми. Зменшення може відбуватися переглядом заходів програми, які можуть бути обрані під скорочення фінансування.

Результати скорочення можуть бути охарактеризовані фінансовими збитками для заходів програми, які у свою чергу, поведуть до погіршення вартісних або натуральних показників виконання програми. Тобто, $x_{n}-$ це збитки (втрати) у гривнях, що понесе захід $n$ програми, $P_{n}-$ імовірність таких збитків. Перейдемо до можливої ситуації із обранням заходів програми для можливого скорочення їх фінансування.

Припустимо, що можуть бути обрані 20 заходів під скорочення фінансування деякої програми i, як мінімум, два варіанти розподілу скорочень їх фінансування.

Варіант 1. За цим варіантом у 9 заходах збитки очікуються 20 тис. грн за кожним заходом (імовірність цієї події $9: 20=0,45$ ), у 6 заходах збитки очікуються 25 тис. грн за кожним заходом (імовірність цієї події $6: 20=$ 0,30), у 5 заходах збитки очікуються 30 тис. грн за кожним заходом (імовірність цієї події $5: 20=0,25$ ).

Середнє очікуване значення збитків на один захід при скороченні фінансування програми за варіантом 1 складатиме:

$$
B(x)=20 \cdot 0,45+25 \cdot 0,30+30 \cdot 0,25=24 \text { тис. грн. }
$$

Варіант 2. За цим варіантом у 8 заходах збитки очікуються 19 тис. грн за кожним заходом, у 7 заходах збитки очікуються 24 тис. грн за кожним заходом, у 5 заходах збитки очікуються 31 тис. грн за кожним заходом.

Середнє очікуване значення збитків на один захід при скороченні фінансування програми за варіантом 2 складатиме:

$$
\begin{gathered}
B(x)=19 \cdot(8: 20)+24 \cdot(7: 20)+31 \cdot(5: 20)= \\
=23,75 \text { тис. грн. }
\end{gathered}
$$

Порівнюючи величини очікуваних збитків при скороченні асигнувань програми за варіантами 1 і 2 можна зробити висновок, що величина збитків за варіантом 1 знаходиться у межах від 20,0 до 30,0 тис. грн на один захід, а середня величина складає 24,0 тис. грн. $3 a$ варіантом 2 величина очікуваних збитків знаходиться у межах від 19 до 31 тис. грн на один захід, а середня величина складає 23,75 тис. грн.

На перший погляд більш вигідним постає варіант 2 тому, що середня величина очікуваних збитків для нього менша.

Однак, середня величина збитків являє собою узагальнену кількісну характеристику і не дозволяє прийняти остаточне рішення яким саме варіантом здійснювати 
скорочення асигнувань. Для кінцевого рішення необхідно виміряти коливання (діапазон відхилень або - змінність) показників, тобто визначити міру коливання можливого результату, тобто збитків.

Коливання можливого результату являє собою ступень відхилення очікуваного значення результату від його середньої величини. Для визначення ступеня в практиці статистичних розрахунків розраховують дисперсію або середньо-квадратичне відхилення.

Як відомо, дисперсія представляє собою середнє зважене із квадратів відхилень дійсних результатів від середніх очікуваних:

$$
\sigma^{2}=\frac{\sum(x-\bar{x})^{2} \mathrm{~A}}{\sum \mathrm{A}}
$$

де $\sigma^{2}$ - дисперсія; $x$ - очікуване значення для кожного випадку спостережень; $\bar{X}$ середнє (середнє-арифметичне) очікуване значення; $A$ - частота випадків, або число спостережень.

Для прикладу, що розглядаються, $x$ очікуване, а $\bar{X}$ - середнє очікуване значення збитків від скорочення асигнувань для кожного із розглянутих заходів бюджетної програми, які обрані для зменшення фінансування; $A$ - кількість заходів, що обрані для зменшення фінансування.

Середнє квадратичне відхилення визначається за формулою:

$$
\sigma=\sqrt{\frac{\sum(x-\bar{x})^{2} \mathrm{~A}}{\sum \mathrm{A}}}
$$

Дисперсія $\sigma^{2}$ i середнє квадратичне відхилення $\sigma$ являються мірами абсолютного коливання. Вони вимірюються у тих же одиницях, що і варіююча ознака. Для наведеного прикладу варіююча ознака - це збитки у грн від скорочення асигнувань заходів програми.

Для аналізу ступеня відхилення очікуваного значення від його середньої величини використовують показник ступеня коефіцієнт варіації - відношення середнєквадратичного відхилення до середнєочікуваного значення:

$$
v=\frac{\sigma}{\bar{x}} \cdot 100,
$$

де $v$ - коефіцієнт варіації, \%.

Коефіцієнт варіації дозволяє порівнювати коливання ознак, що мають різні одиниці виміру. Чим більше коефіцієнт варіації, тим сильніше коливання ознаки. В практиці застосувань статистичного методу кількісного аналізу ризиків встановлені наступні оцінки варіації ризиків:

- до 10\% - слабке коливання;

- 10-25\% - помірне коливання;

- більше 25\% - високе коливання.

Для розглянутого прикладу середнєквадратичне відхилення дорівнює:

для варіанту 1 розподілу зменшення асигнувань між заходами програми:

$$
\begin{gathered}
\sigma_{1}^{2}=\frac{(20-24)^{2} \cdot(25-24)^{2} \cdot 6+(30-24)^{2} \cdot 5}{20}=16,5 \text { тис. грн } \\
\sigma_{1}=\sqrt{16,5}=4,06 \text { тис. грн }
\end{gathered}
$$

для варіанту 2: розподілу зменшення асигнувань між заходами програми:

$$
\begin{gathered}
\sigma_{2}^{2}=\frac{(19-23,75)^{2} \cdot 8+(24-23,75)^{2} \cdot 7+(31-23,75)^{2} \cdot 5}{20}=14,4 \text { тис. грн } \\
\sigma_{2}=\sqrt{14,4} \approx 3,75 \text { тис. грн. }
\end{gathered}
$$

Коефіцієнт варіації (коефіцієнт ризику):

1 варіант: $v_{1}=(4,06: 24) \cdot 100=16,9 \%$;

2 варіант: $v_{2}=(3,75: 23,75) \cdot 100=15,9 \%$.

Тобто для початкових умов обох можливих варіантів скорочення фінансування програми коефіцієнти варіації знаходяться у діапазоні значень помірного коливання.

Однак, коефіцієнт варіації при зменшенні обсягу фінансування програми за варіантом 2 
менший, чим при зменшенні фінансування програми за варіантом 1.

Тому варіант 2 менш ризиковий і більш доцільний. В цілому для варіанту 2 виявляються більш позитивними два чинники: менше середнє значення очікуваних збитків і менший показник ризику у отриманні збитків у порівнянні із варіантом 1.

Табл. 1. - Відхилення прогнозованої економії

\begin{tabular}{|c|c|c|c|}
\hline $\begin{array}{c}\text { Варіант розподілу } \\
\text { замовлень }\end{array}$ & $\begin{array}{c}\text { Нижня межа } \\
\text { можливих збитків }\end{array}$ & $\begin{array}{c}\text { Середнє значення } \\
\text { очікуваних збитків }\end{array}$ & $\begin{array}{c}\text { Верхня межа можливих } \\
\text { збитків }\end{array}$ \\
\hline варіант 1 & 19,94 & 24 & 28,06 \\
\hline варіант 2 & 19.97 & 23,75 & 27.5 \\
\hline
\end{tabular}

Незважаючи на майже однакові значення нижчих меж збитків для обох варіантів скорочення програми середнє значення та верхня межа збитків для варіанту 2 менші, чим для варіанту 1.
Якщо застосувати коефіцієнти варіації до визначення нижньої та верхньої меж відхилення прогнозованих збитків від їх середніх значень для порівняних варіантів скорочення фінансування програми, то отримаємо такі показники у тис. грн для одного заходу програми, табл. 1.

Таким чином, абсолютні середні і порогові значення прогнозованих збитків для можливих варіантів скорочення фінансування програми впевнено свідчать про пріоритетність вибору варіанту 2 у порівнянні з варіантом 1.

Табл. 2. - Порівняльна таблиця можливих варіантів скорочення фінансування бюджетної програми

\begin{tabular}{|c|c|c|c|c|c|c|c|c|c|c|c|c|c|}
\hline \multirow{3}{*}{ 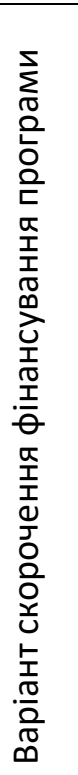 } & \multicolumn{6}{|c|}{$\begin{array}{c}\text { Групи заходів, що набувають } \\
\text { збитків в наслідок зменшення } \\
\text { (припинення) фінансування }\end{array}$} & \multicolumn{6}{|c|}{$\begin{array}{c}\text { Показники кількісного аналізу збитків (втрат) та } \\
\text { ризиків їх виникнення при скороченні } \\
\text { фінансування програми } \\
\end{array}$} & \multirow{3}{*}{ 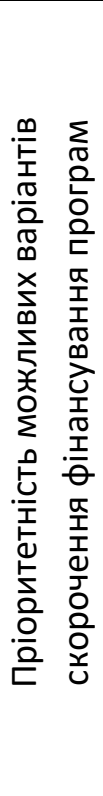 } \\
\hline & \multicolumn{2}{|c|}{ I } & \multicolumn{2}{|r|}{ II } & \multicolumn{2}{|c|}{ III } & \multirow[b]{2}{*}{ 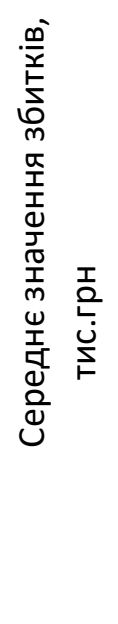 } & \multirow[b]{2}{*}{ 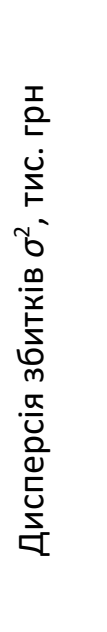 } & \multirow[b]{2}{*}{ 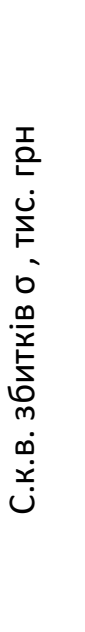 } & \multirow[b]{2}{*}{ 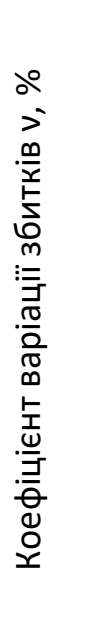 } & \multirow[b]{2}{*}{ 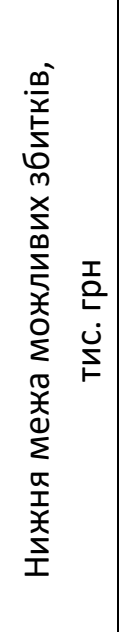 } & \multirow[b]{2}{*}{ 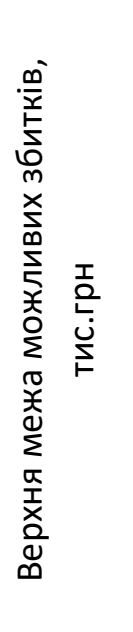 } & \\
\hline & 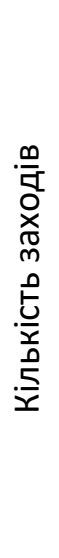 & 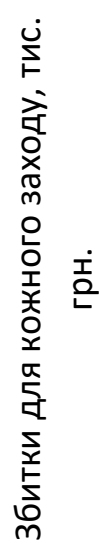 & 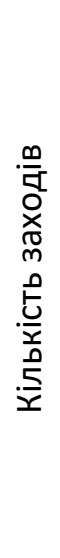 & 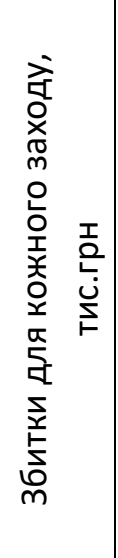 & 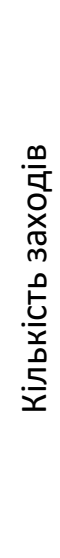 & 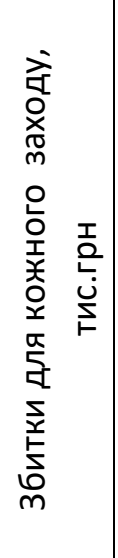 & & & & & & & \\
\hline 1. & 9 & 20 & 6 & 25 & 5 & 30 & 24 & 16,5 & 4,06 & 16,9 & 19,94 & 28,06 & 2 \\
\hline 2. & 8 & 19 & 7 & 24 & 5 & 31 & 23.75 & 14.4 & 3.75 & 15.9 & 19.97 & 27.5 & 1 \\
\hline$\cdots$ & & & & & & & & & & & & & \\
\hline
\end{tabular}

Тому, якщо зменшення фінансування програми неможливо уникнути, то для мінімізації втрат (результативності) ії виконання, реалізацію зменшення асигнувань програми доцільно проводити шляхом зменшення асигнувань 
(тобто нанесення не уникливих збитків) для заходів програми, передбачених у варіанті 2 управлінських дій.

Розглянутий підхід може застосовуватися і при наявності більш, чим двох альтернативних варіантів, а також більш чим трьох можливих груп заходів у конкретному варіанті, що можуть підпадати під скорочення фінансування. До того ж, для крупних бюджетних програм одиницями виміру можуть бути не тисячі, а мільйони гривень.

Результати розрахунків можуть бути зведені в підсумкову таблицю, за якою зручніше порівнювати можливі варіанти скорочення фінансування програми та здійснювати висновки стосовно найбільш прийнятного варіанту.

\title{
Висновки
}

Розглянутий підхід до оцінювання можливих варіантів

скорочення

фінансування бюджетної програми (програм) може розглядатися як додаткова методика обґрунтування вибору для Розпорядника коштів найбільш доцільного та найменш ризикового варіанту.

Він не відміняє та не замінює існуючих правил корегування бюджетних програм під час їх формування і виконання, не протирічить ним та може бути застосований як додатковий механізм попереднього вивчення Розпорядником пропозицій підлеглих або як один із завершальних заходів при підготовці до прийняття кінцевого рішення щодо скорочення фінансування бюджетної програми.

Подальший розвиток запропонованого підходу може бути пов'язаний із формалізацією його як алгоритму i розробкою програмного забезпечення для формування підсумкової порівняльної таблиці можливих варіантів скорочення фінансування бюджетної програми та створенням вихідної довідкової інформації (банку даних) щодо очікуваних втрат (збитків) від зменшення фінансування окремих заходів для критичних із забезпечення 3С бюджетних програм.

\section{Список використаних джерел}

1. Ткач І. М. Концептуальні засади воєнноекономічної безпеки держави : монографія. Київ : НУОУ ім. І. Черняховського, 2018. 312 c. ISBN 978-617-7187-19-5

2. Горбулін В. П., Шеховцов В. С., Шевцов А. І. Проблеми державного регулювання цін на продукцію оборонно-промислового комплексу України. Стратегічні пріоритети. 2014. № 2 (31). С. 105-111.

3. Іванова І. М. Особливості формування вартості продукції оборонного призначення. Стратегічні пріоритети. 2016. № 2 (39). С. 82-87.
4. Павловський І. В., Чепков І. Б., Борохвостов В. К., Борохвостов І. В., Рябець О. М. Науковометодичні підходи до аналізу воєннотехнічних та техніко-економічних аспектів життєвого циклу зразків озброєння та військової техніки. Наука і оборона. 2017. № 2. C. $43-51$.

5. Ткач І. М., Панасенко Л.І. Воєнноекономічний аналіз : підручник. Київ : НУОУ ім. Івана Черняховського, 2013. 264 с.

6. Ткач І. М., Новіков Е.Б. Методи економічних досліджень : навч. посіб. Київ : НУОУ ім. Івана Черняховського, 2015. 184 с.

\section{Минимизация потерь бюджетной программы при уменьшении ее финансирования}

\author{
Павел Пархоменко ${ }^{A}$ \\ А Национальный университет обороны Украины имени Ивана Черняховського, \\ старший преподаватель кафедры экономики и финансового обеспечения, e-mail: mpar88@ukr.net
}




\begin{abstract}
Аннотация
Рассмотрена одна из проблем, которая возникает в повседневной практике руководящего состава - распорядителей средств при принятии управленческих решений. А именно необходимость перераспределения ассигнований между бюджетными программами и избрание меры, сокращение финансирования которых можно меньше скажется на результативности программы и минимизирует риски невыполнения программы в целом.

Для решения проблемы предложен подход с применением статистического метода количественного анализа рисков на основании определения двух показателей: вероятности получения потерь (убытков) в случае сокращения финансирования программы и среднего значения и диапазона колебания этих ожидаемых потерь (убытков).

Приведенный пример использования предложенного подхода для двух возможных вариантов сокращения финансирования некоторой программы между тремя потенциальными группами мероприятий этой программы. Предложенный механизм возведения расчетов в итоговую таблицу, приемлемую для анализа и принятия окончательного решения в инстанции управления по выбору маленький рискового варианта.

Указано, что рассматриваемый подход может быть применен и при наличии более чем двух альтернативных вариантов сокращения финансирования программы и для более чем трех потенциальных групп мероприятий избираемых для уменьшения финансирования.
\end{abstract}

Ключевые слова: вариант сокращения финансирования программы, вероятность потерь (убытков), среднее значение потерь (убытков), коэффициент вариации потерь (убытков).

\title{
Minimization of losses of the budget program at reduction of its financing
}

\author{
Pavlo Parkhomenko A \\ A The National Defence University of Ukraine named after Ivan Cherniakhovskyi, Senior lecturer, e-mail: mpar88@ukr.net
}

\begin{abstract}
One of the problems that arise in the daily practice of management - fund managers in making management decisions is considered. Namely, the need to redistribute appropriations between budget programs and select measures that reduce funding the least will affect the effectiveness of the program and minimize the risks of non-implementation of the program as a whole.

To solve the problem, an approach is proposed using a statistical method of quantitative risk analysis based on the definition of two indicators: the probability of losses (losses) in the event of a reduction in program funding and the average and range of these expected losses (losses).

An example of using the proposed approach for two possible options for reducing funding for a program between the three potential groups of activities of this program. The mechanism of summary of calculations in the final table acceptable for the analysis and acceptance of the final decision in an instance of management concerning a choice of the least risky variant is offered.

It is noted that this approach can be applied in the presence of more than two alternatives to reduce funding for the program and for more than three potential groups of measures selected to reduce funding.
\end{abstract}

Keywords: option to reduce the funding of the program, the probability of losses (losses), the average value of losses (losses), the coefficient of variation of losses (losses).

\section{References}

1. Tkach I. M. (2018) Kontseptual'ni zasady voyenno-ekonomichnoyi bezpeky derzhavy
[Conceptual principles of military and economic security of the state] monograph. 
Kyiv: NUDU, 312 p. (in Ukraine)

2. Gorbulin V. P, Shekhovtsov V. S, Shevtsov A. I. (2014) Problems of state regulation of prices for products of the defense-industrial complex of Ukraine. Strategic priorities. No. 2 (31). S. 105-111. (in Ukraine)

3. Ivanova I. M. (2016) Features of formation of the value of defense products. Strategic priorities. No. 2 (39). Ss. 82-87. (in Ukraine)

4. Pavlovsky I.V., Chepkov I.B., Borokhvostov V.K., Borokhvostov I.V., Ryabets O.M. (2017) Scientific and methodological approaches to the analysis of military-technical and technicaleconomic aspects of the life cycle of weapons samples and military equipment. Science and defense. № 2. S. 43-51. (in Ukraine)

5. Tkach I. M., Panasenko L. I. Voyennoekonomichnyy analiz [Military-economic analysis]. Kyiv : NUOU, 2013. 264 s. (in Ukraine) 6. Tkach I. M., Novikov E. B. Metody ekonomichnykh doslidzhen' [Methods of economic research]. Kyiv : NUOU, 2015. 184 s. (in Ukraine). 